\title{
Excitotoxicity and Wallerian degeneration as a processes related to cell death in nervous system
}

\author{
J. DZIAŁO', B. TOKARZ-DEPTUŁA², W. DEPTUŁA ${ }^{1}$ \\ ${ }^{7}$ Department of Microbiology, Faculty of Biology, University of Szczecin, Poland; \\ ${ }^{2}$ Department of Immunology, Faculty of Biology, University of Szczecin, Poland
}

\begin{abstract}
A B S T R A C T
Cell death is one of the processes that are currently extensively studied. Beside the commonly used terminology regarding cell death, i.e. apoptosis, autophagy, necrosis, and cornification, in recent years there has been a growing number of additional definitions of this process, such as mitotic catastrophe, anoikis, entosis, paraptosis, pyroptosis, pyronecrosis, excitotoxicity, and Wallerian degeneration, which are described as atypical by the 2009 Nomenclature Committee on Cell Death. The recent report of that Committee significantly alter the classification and nomenclature of the cell death processes, in which excitotoxicity and Wallerian degeneration have not been taken into account. Thus the present review describes excitotoxicity, and Wallerian degeneration, as two processes associated to cell death phenomena characteristic for nervous system.

Excitotoxicity is a neuronal death caused by excessive, or prolonged activation of receptors for the excitatory amino acids. Depending on the intensity of the initiating stimulus, the excitotoxicity may overlap with other types of cell death such as apoptosis and necrosis.

Wallerian degeneration is a process that results when a nerve fiber is cut or crushed, in which the part of the axon separated from the neuron's cell body degenerates distal to the injury. Wallerian degeneration is not a typical cell death mechanism, since neurons undergoing this process remain alive.
\end{abstract}

Key words

Cell death $\bullet$ Excitotoxicity $\bullet$ Wallerian degeneration

\section{Introduction}

For many years cell death has been a subject of extensive studies of scientist from all over the world. The processes of cell death occur in healthy, as well as pathologically changed tissues of the organism. Until recently it was considered the existence of four basic types of cell death: apoptosis, autophagy, necrosis, and cornification (keratinization), based on the recommendation of the NCCD (The Nomenclature Committee on Cell Death, 2009). Apoptosis is a type of programmed cell death mediated by caspases, during which some characteristic features can be observed, such as: reduction of cellular volume, condensation and fragmentation of chromatin, formation of apoptotic bodies, and their phagocytosis by neighboring phagocytes, but without induction of inflammation processes (Kroemer et al., 2009). Necrosis is cell death accompanied with local inflammation and is characterized by a gain in cell volume (oncosis), swelling of organelles, plasma membrane rupture and subsequent release of the cellular contents into the intracellular space (Kroemer et al., 2009). Autophagy, in terms of cell death process, is defined as a type of cell death proceeding without chromatin condensation, but 
with an intense vacuolization of the cytoplasm, and autophagosome formation (Kroemer et al., 2009). Cornification is a very specific type of programmed cell death, which leads to formation of corneocytes - dead keratinocytes containing structural proteins, fatty acids, and ceramides (Kroemer et al., 2009). Moreover, mentioned guidelines of the NCCD (Kroemer et al., 2009), give tentative definitions of 8 atypical cell death modalities: mitotic catastrophe, anoikis, entosis, paraptosis, pyroptosis, pyronecrosis, excitotoxicity, and Wallerian degeneration. Mitotic catastrophe is a form of cell death occurring during, or shortly after abnormal mitosis, which is accompanied by multi-nucleation and/or formation of micronuclei from the chromosomes and their fragments that have not been evenly distributed between daughter nuclei during mitosis (Green et al., 2009). Anoikis and entosis belong to atypical cell death mechanisms connected with interruption or loss of the proper cell-cell, and cell-ECM (extracellular matrix) adhesions (Gilmore, 2005; White, 2007). The term paraptosis was introduced to describe a programmed cell death (PCD) distinct from apoptosis, which occurs only when a specific set of genes is activated (Krantic et al., 2007; Sperandio et al., 2000). The processes of pyroptosis and pyronecrosis are similar forms of atypical programmed cell death, connected with the reaction of the immune system to infections. Their characteristic features include the involvement of Nod like receptors (NLR) in their induction, and formation of protein complexes termed inflammasomes (Bergsbaken et al., 2009; Ting et al., 2008). Finally, there are two cell death modalities such as excitotoxicity and Wallerian degeneration, which are characteristic exclusively for the cells of the nervous system (Kroemer et al., 2009). While the basic cell death types (apoptosis, necrosis, autophagy) in nervous system are relatively well known (for review: Lossi et al., 2005; Yuan et al., 2003; Yue et al., 2009), the knowledge about the mechanisms of this two atypical modes of death or partially degeneration in cells of the nervous system is still scarce, although there is a lot of extensive studies in this subject. It is also important, that recently published new recommendations of The Nomenclature Committee on Cell Death (Galluzzi et al., 2012) significantly alter the classification and nomenclature of the cell death processes, and excitotoxicity and Wallerian degeneration have not been taken into account there. Hence the purpose of this review is to describe the phenomena occurring in the nervous system: excitotoxicity and Wallerian degeneration as a process of cell death or partial degeneration.

\section{Excitotoxicity}

In 1969 Olney introduced the term "excitotoxicity" in his study on the effect of monosodium glutamate on brain functions in mice, to describe the neuronal death caused by excessive, or prolonged activation of receptors for the excitatory amino acids, among which glutamate plays the key role. Similar observations were made in regard to the ionotropic, and to a lesser extent metabotropic receptors (Casson and Franzo, 2006; Deng et al., 2006; Montoliu et al., 2002). It should be underlined, that the glutamate receptors are divided into two groups: ionotropic glutamate receptors (iGluR), connected with ion channels, whose activation leads to permeability of these channels to bivalent cations (such as $\mathrm{Ca}^{2+}$ ), and metabotropic glutamate receptors (mGluR), whose activation leads to mobilization of the endogenous calcium pool via mechanisms dependent on the GTP-binding protein (Duncan, 2009). The iGluR are ligand-gated ion channels mediating the fast synaptic transmission (Casson and Franzo, 2006). They are characterized by their selective affinity to specific agonists (ligands), such as: $N$-methylD-aspartate to the NMDA receptor (NMDAR), $\alpha$-amino-3-hydroxy-5-methyl-4-isoxazole propionic acid to the AMPA receptor (AMPAR), and kainic acid to the KA receptor (KAR) (Hynd et al., 2004; Vincent and Mulle, 2009). In case of the metabotropic glutamate receptors, they are divided into three groups (mGluRI-mGluRIII) on the basis of their amino acids sequence, sensitivity to their agonists, and the ability of signal transduction (Hynd et al., 2004). The mGluRs were not shown to play an important role in the excitotoxicity, although their involvement in this process was described in the white matter, and to smaller extent in the grey matter of CNS (Casson and Franzo, 2006). Studies of Deng and coworkers (2006) indicate, that this process can concern not only neurons, but also oligodendrocytes. The NMDA receptor is best known for its function, as well as its role in excitotoxicity. NMDAR shows 
higher permeability to calcium cations than the two other ionotropic receptors, which is the reason for its greater ability to induce the $\mathrm{Ca}^{2+}$ cytosolic overload, leading to cell death (Duncan, 2009; Hynd et al., 2004). Activation of these receptors causes deregulation of the ionic homeostasis in cells, mainly regarding a significant increase of $\mathrm{Ca}^{2+}$ ions, which leads to cell death (Casson and Franzo, 2006; Kroemer et al., 2009). It has been demonstrated that in addition to calcium ions, free radicals and nitrogen oxide are also involved in this process (Fig. 1). The intracellular events during the excitotoxicity are

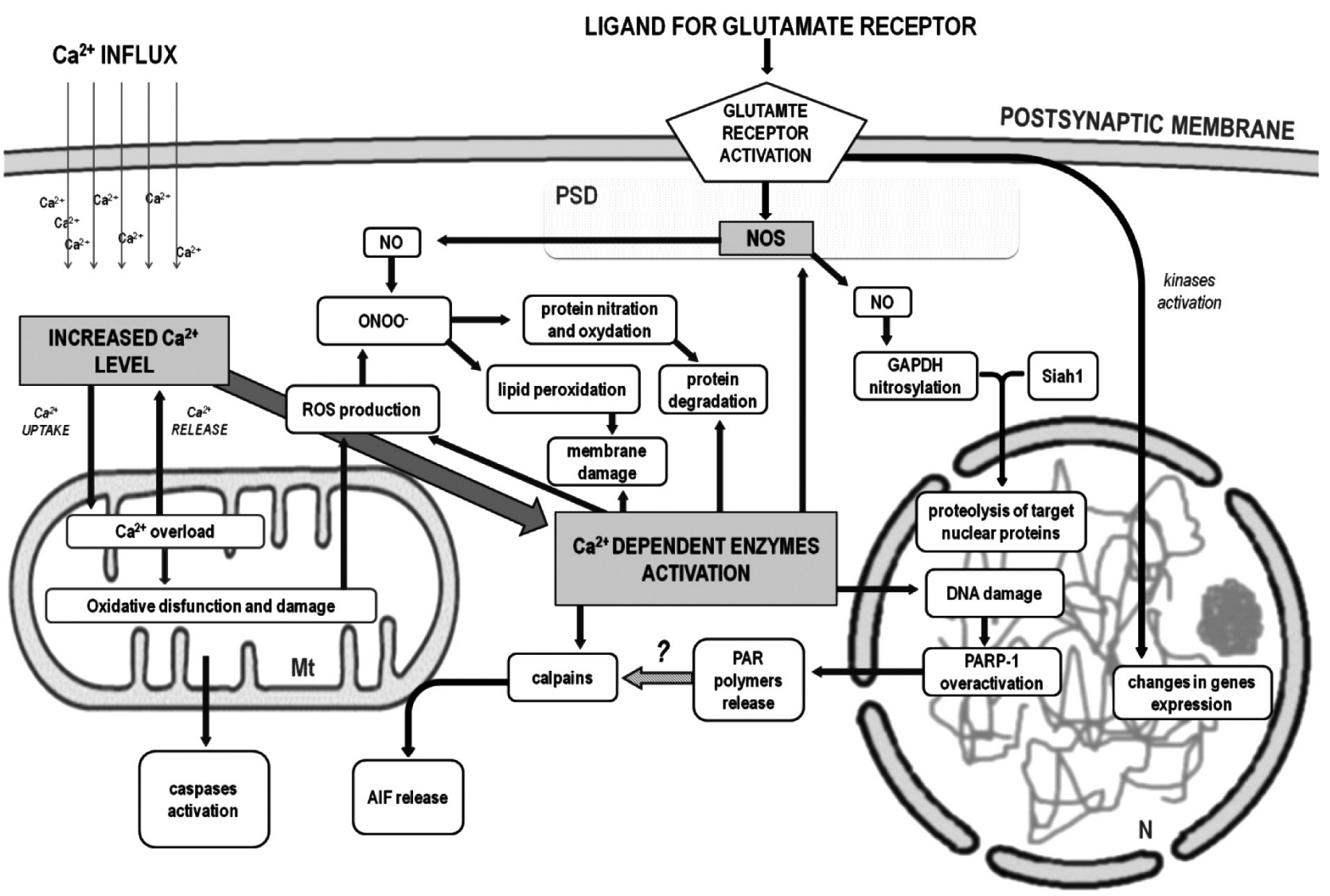

Fig. 1. - Overview on cell changes during excitotoxicity (Lau and Tymianski 2010; Metha et al., 2013; Flores-Soto et al., 2012).

Excessive activation of ionotropic glutamate receptors localized on postsynaptic membrane causes massive influx of calcium ions $\left(\mathrm{Ca}^{2+}\right)$ into the cell. Such increase of cytoplasmic calcium concentration can trigger a range of downstream events which lead to cell death. Excess of calcium ions is sequestered into mitochondria (Mt) and the overload of this organelles with calcium causes their dysfunction and damage. Dysfunctional or damaged mitochondria release calcium ions to cytoplasm as well as large amount of reactive oxygene species (ROS). Additionally metabolic dysfunction of mitochondrium can lead to caspase activation. Increased level of cellular calcium causes disrupted activation of calcium-dependent enzymes such as proteases including calpains, phospholipases, endonucleases, oxidases and nitric oxide synthase (NOS) which can cause production of ROS and/or damage of various cellular elements. On the other hand glutamate receptors are also linked to NOS through one of the post synaptic density protein (PSD), thus NOS can produce toxic levels of nitric oxide (NO) after glutamate receptor activation. NO can be toxic for neuron in at least two pathways. Firstly NO interacts with free radical superoxide to form peroxynitrite (ONOO-) which causes primarily protein nitration and oxidation and lipid peroxidation leading to cell death. Secondly NO can cause nitrosylation of glyceraldehydes 3-phosphate dehydrogenase (GAPDH), which subsequently binds to ubiquitin ligase (Siah1) and translocates to the nucleus $(\mathrm{N})$ where proteasomes degrades Siah1 targets protein. Finally peroxynitrite can directly damage DNA. Damaged DNA activates poly-ADP-ribose polymerase 1 (PARP-1) leading to release polymers of poly-ADP-ribose (PAR) to cytoplasm, which in turns cause calpains activation by unknown mechanism (?) and subsequent release of apoptosis inducing factor (AIF) from mitochondria. Moreover activation of glutamate receptors can lead to protein kinases activation and subsequent downstream signaling causes changes in gene expression. The consequence of all these events can be disruption of cellular homeostasis leading to apoptotic or necrotizing cell death depending on intensity of stimuli. 
still not fully understood, but it is now clear that in this process cysteine proteases, mitochondrial endonucleases, poly (ADP-ribose) polymerase 1 (PARP1) and Glyceraldehyde 3-phosphate dehydrogenase (GAPDH) could be required (Lau and Tymianski, 2010). The excitotoxicity is observed during brain damage, strokes, cardiac arrest, epilepsy, hypoxia, hypoglycemia, cerebral ischemia, and neurodegenerative diseases, such as: amyotrophic lateral sclerosis, and Huntington's, Alzheimer's, and Parkinson's diseases (Bevers et al., 2009; Montoliu et al., 2002; $\mathrm{Wu}$ and $\mathrm{Li}, 2009$ ). For this reason many studies are conducted on the influx of different substances in excitotoxic neuronal death (Table I).

The latest reports indicate that the postsynaptic density proteins (PSD) also play an important function in excitotoxicity. PSD is a multiprotein structure connected with the postsynaptic membrane (Forder and Tymianski, 2009). Among several hundreds of proteins assembled within this large complex the ionotropic receptors are also found. These receptors form a complicated spatial network in conjunction with protein kinases, phosphatases, and cytoskeletal proteins, which localizes these proteins near the postsynaptic membrane, forming specific signaling pathways (Forder and Tymianski, 2009). Depending on the intensity of the initiating stimulus, the excitotoxicity may overlap with other types of cell death such as apoptosis and necrosis, however during this process the specific regulatory factors are not observed (Ientile et al., 2001; Kroemer et al., 2009). Because of these properties of excitotoxicity, NCCD does not classify this process as a separate, functional type of cells death, but define it as atypical cell death modality.

\section{Wallerian degeneration}

The process described as Wallerian degeneration was first described over 100 year ago by August Waller, who observed this specific phenomenon during his studies on lesioned hypoglossal, and glossopharyngeal nerves in frogs (Koeppen, 2004). The Wallerin degeneration (WD) takes place after axonal rupture in both central, and peripheral nervous systems (CNS and PNS), although in case of the CNS the process progresses in a much slower rate (Koeppen, 2004; Raff et al., 2002). The part of the axon, which was detached from the neuron's cell body in the course of the injury, is degenerating in a characteristic manner, through degradation of the endoplasmic reticulum and neurofilaments by ionsensitive proteases, such as: calpains. Swelling of axonal mitochondria occurs, leading to their lysis, and the whole damaged part of the axon, separated from the neuron, is disintegrated into smaller pieces, which are removed by macrophages and Schwann cells in the PNS, or by activated microglia in the CNS (Luo and O'Leary, 2005; Raff et al., 2002; Wang et al., 2009; Yamagishi et al., 2005). It is thought, that the astrocytes may also be involved in phagocytosis of the damaged axons, and subsequently proliferate in order to fill in the space left after the phagocytized neural fibers (Wang et al., 2009). Even though the Wallerian degeneration has been known for a long time, the molecular mechanism of this process remains unrevealed, however it has been noted that it is caspase-independent, and it proceeds independently of the neuron death (Koike et al., 2008; Saxena and Caroni, 2007; Yamagishi et al., 2005). Additionally, after a discovery of spontaneous mouse Wld ${ }^{\mathrm{s}}$ mutants (Wallerian degeneration slow) in 1989, showing significantly delayed and protracted WD, the perception of the process changed, and nowadays it is no longer considered as passive, caused by deprivation of nutrients supplied by the neuron's cell body, but as an active program of axonal degeneration (Hilliard, 2009). This breakthrough discovery provided many new data and expanded the knowledge on the Wallerian degeneration (Koeppen, 2004). It has been shown, that the mutation in Wlds mice results from a tandem triplication of a $85 \mathrm{~kb}$ fragment within chromosome 4 , causing formation of a new chimeric protein Wld composed of a complete amino acid sequence of nicotinamide mononucleotide adenylyl transferase (Nmnat), N-terminal 70 amino acids fragment of Ufd2 protein (ubiquitin fusion degradation protein 2 ), and a short peptide sequence that joins the two proteins together (Hilliard, 2009; Koike et al., 2008). The effect of this protein on the WD has been a subject of many extensive studies in the recent years. It has been reported that the $\mathrm{Wld}^{\mathrm{s}}$ protein is expressed only in the nuclei, and is not found in axons, which suggests that this protein may regulate the expression of other proteins that initiate the Wallerian degeneration (Saxena and Caroni, 2007). The role of 


\begin{tabular}{|c|c|c|c|c|}
\hline Examined factor & Material & $\begin{array}{l}\text { Glutamate } \\
\text { receptor type }\end{array}$ & Results summary & Reference \\
\hline $\begin{array}{l}\text { ConantokinG (CGX- } \\
\text { 1007)-antagonist of } \\
\text { NR2B subunit of NMDAR }\end{array}$ & $\begin{array}{l}\text { Hippocampal brain } \\
\text { slice cultures from } \\
\text { Sprague Dawley rat } \\
\text { pups }\end{array}$ & NMDAR & $\begin{array}{l}\text { This factor inhibited NMDA-induced } \\
\text { neuronal excitotoxicity through the } \\
\text { blocking of different subtypes of } \\
\text { NMDAR. }\end{array}$ & Alex et al., 2011 \\
\hline $\begin{array}{l}\text { KN93, tat-AIP, tat-CN21- } \\
\text { inhibitors of calcium- } \\
\text { calmodulin (CaM)-de- } \\
\text { pendent protein kinase } \\
\text { II (CaMKII) }\end{array}$ & $\begin{array}{l}\text { Embryonic cortical } \\
\text { neuron culture from } \\
\text { Sprague Dawley rat } \\
\text { pups }\end{array}$ & NMDAR & $\begin{array}{l}\text { Inhibition of CaMKII activity in cells } \\
\text { exposed to NMDA, shortly after stimu- } \\
\text { lation of the substance protects neu- } \\
\text { rons against excitotoxicity, increasing } \\
\text { their survival. While the permanent } \\
\text { loss of the kinase activity increase } \\
\text { susceptibility of neurons to glutamate } \\
\text { caused excitotoxicity. }\end{array}$ & $\begin{array}{l}\text { Ashpole and } \\
\text { Hudmon, } 2011\end{array}$ \\
\hline $\begin{array}{l}\text { Tumor necrosis factor } \alpha \\
(\text { TNF- } \alpha \text { ) }\end{array}$ & $\begin{array}{l}\text { Cerebella from } \\
\text { postnatal 9-12 day } \\
\text { old Sprague Dawley } \\
\text { rats }\end{array}$ & AMPAR & $\begin{array}{l}\text { This factor has intensified the excitoto- } \\
\text { xicity in the examined cells exposed } \\
\text { to AMPA. In these cells, there was in- } \\
\text { creased activity of calpains caused } \\
\text { by increased influx of calcium ions. }\end{array}$ & Bliss et al., 2011 \\
\hline $\begin{array}{l}\text { Vascular Endothelial } \\
\text { Growth Factor (VEGF-A) }\end{array}$ & $\begin{array}{l}\text { Motor neurons cul- } \\
\text { ture from Wistar rats }\end{array}$ & AMPAR & $\begin{array}{l}\text { This factor prevented excitotoxicity } \\
\text { involving AMPA receptors, and its } \\
\text { mechanism of action was to intensi- } \\
\text { fying transcription of GluR2 subunit } \\
\text { of AMPA receptor, which meant that } \\
\text { the receptor was not permeable to } \\
\text { calcium ions. }\end{array}$ & $\begin{array}{l}\text { Bogaert et al., } \\
2010\end{array}$ \\
\hline Lithium & $\begin{array}{l}\text { Organotypic slice } \\
\text { culture of spinal } \\
\text { cord from E16 chick } \\
\text { embryos }\end{array}$ & KAR & $\begin{array}{l}\text { This factor prevented the excitotoxi- } \\
\text { city with participation of KA receptor, } \\
\text { but also caused large cytopathic } \\
\text { changes and did not prevent apop- } \\
\text { tosis. He acted by blocking GSK-3 } \beta \text {. }\end{array}$ & $\begin{array}{l}\text { Caldero et al., } \\
2010\end{array}$ \\
\hline $\begin{array}{l}\text { Cationic liposomes } \\
\text { associated to transferrin } \\
\text { (Tf-lipoplexes) with anti- } \\
\text { C-Jun siRNAs }\end{array}$ & $\begin{array}{l}\text { Primary mouse } \\
\text { embryonic cortical } \\
\text { neurons from: C57/ } \\
\text { BL6 mice for in vitro } \\
\text { studies; C57BL/6 } \\
\text { mice for in vivo } \\
\text { studies }\end{array}$ & KAR & $\begin{array}{l}\text { This factor effectively inhibited the ex- } \\
\text { pression of c-Jun after KA stimulation, } \\
\text { which resulted in reduced neuron } \\
\text { death both in vitro and in vivo. These } \\
\text { results suggest that the factor can } \\
\text { be an effective therapeutic tool for } \\
\text { treatment of neurodegenerative } \\
\text { diseases which are accompanied by } \\
\text { excitotoxicity. }\end{array}$ & $\begin{array}{l}\text { Cardoso et al., } \\
2010\end{array}$ \\
\hline $\begin{array}{l}\text { 2-methyl-6- } \\
\text { (phenylethynyl)-pyridine } \\
\text { (MPEP)-mGlu5 receptor } \\
\text { antagonist }\end{array}$ & $\begin{array}{l}\text { Mixed spinal cord } \\
\text { cultures (MSCs) } \\
\text { from 13-15 old } \\
\text { Wistar rat embr- } \\
\text { yos; astroglial cell } \\
\text { cultures from spinal } \\
\text { cord of Wistar new } \\
\text { born rats }\end{array}$ & AMPAR & $\begin{array}{l}\text { Prolonged pre-exposure to the } \\
\text { selective mGlu5 receptor antago- } \\
\text { nist, MPEP, protected motor neurons } \\
\text { (MNs) in MSCs against AMPA toxicity. } \\
\text { This probably has happened due to } \\
\text { reduction of brain derived neurotro- } \\
\text { phic factor (BDNF) expression and } \\
\text { down-regulation of GluR1 subunits of } \\
\text { AMPA receptors. Blocking of mGlu5 } \\
\text { could be a novel target for treatment } \\
\text { MNs disorders, for example ALS. }\end{array}$ & $\begin{array}{l}\text { D'Antoni et al., } \\
2011\end{array}$ \\
\hline $\begin{array}{l}\text { L-theanine-the major } \\
\text { amino acid from green } \\
\text { tea }\end{array}$ & $\begin{array}{l}\text { Human neurobla- } \\
\text { stoma transgenic } \\
\text { cell line SH-SY5Y } \\
\text { with expression of } \\
\text { APP Swedish muta- } \\
\text { tion as an in vitro } \\
\text { model of Alzhei- } \\
\text { mer's disease }\end{array}$ & NMDAR & $\begin{array}{l}\text { This substance has protected } \\
\text { cells using for experiment against } \\
\text { L-glutamate-induced excitotoxicity. It } \\
\text { was shown that L-theanine acts as } \\
\text { a natural antagonist of glutamate } \\
\text { and prevents the increase of amyloid } \\
\beta \text { secretion induced by the overac- } \\
\text { tivation of NMDAR. Thus it could be } \\
\text { using as a prophylaxis and treatment } \\
\text { agent in Alzheimer's disease. }\end{array}$ & Di et al., 2010 \\
\hline
\end{tabular}


Table I. - Effect of selected factors on the process of excitotoxicity.

\begin{tabular}{|c|c|c|c|c|}
\hline Examined factor & Material & $\begin{array}{l}\text { Glutamate } \\
\text { receptor type }\end{array}$ & Results summary & Reference \\
\hline Rosuvastatin (RST) & $\begin{array}{l}\text { Primary cortical } \\
\text { neurons from E18 } \\
\text { Sprague-Dawley } \\
\text { rat's embryos }\end{array}$ & NMDAR & $\begin{array}{l}\text { Three-day RST pretreatment has } \\
\text { protected cultured neurons against } \\
\text { L-glutamate-induced excitotoxicity. } \\
\text { Mechanisms of protection has likely } \\
\text { involved reduced } \mathrm{Ca}^{2+} \text { influx and } \\
\text { decreased superoxide production. }\end{array}$ & $\begin{array}{l}\text { Domoki et al., } \\
2010\end{array}$ \\
\hline $\begin{array}{l}\text { Idazoxan, } \\
\text { 2-(2-benzofuranyl)- } \\
\text { 2-Imidazoline (2-BFI) } \\
\text { imidazoline } \mathrm{I}_{2} \text { receptor } \\
\text { antagonists }\end{array}$ & $\begin{array}{l}\text { Primary cortical } \\
\text { neurons cell culture } \\
\text { from E15-E16 CD1 } \\
\text { mice embryos }\end{array}$ & NMDAR & $\begin{array}{l}\text { Idazoxan and 2-BFI reversibly block } \\
\text { intracellular calcium influx in cortical } \\
\text { neurons and are neuroprotective } \\
\text { against glutamate toxicity. This } \\
\text { substances can be examined as a } \\
\text { therapeutics to treat excitotoxicity- } \\
\text { mediated neurological disorders and } \\
\text { they are expected to have minimal } \\
\text { side effects toward NMDA receptor } \\
\text { normal physiological functions. }\end{array}$ & Jiang t al. 2010 \\
\hline $\begin{array}{l}\text { Lenti virus expressing } \\
\text { Meteorin-newly identi- } \\
\text { fied neurotrophic factor }\end{array}$ & $\begin{array}{l}\text { Left striatum of } \\
2-3 \text { months old } \\
\text { Sprague-Dawley } \\
\text { rats male; in vivo } \\
\text { studies }\end{array}$ & NMDAR & $\begin{array}{l}\text { Meteorin has protected striatal } \\
\text { neurons against quinolinic acid me- } \\
\text { diated excitotoxicity and it could be } \\
\text { using after additional examination } \\
\text { as a novel therapeutic molecule for } \\
\text { disorders with associated excitotoxici- } \\
\text { ty such as Huntington disease. }\end{array}$ & $\begin{array}{l}\text { Jorgensen } \\
\text { et al., } 2011\end{array}$ \\
\hline $\begin{array}{l}\text { Tacrolimus (FK506)- } \\
\text { immunosuppressant }\end{array}$ & $\begin{array}{l}\text { Organotypic } \\
\text { hippocampal slice } \\
\text { cultures from 6-7 } \\
\text { days old Sprague- } \\
\text { Dawley rats }\end{array}$ & Not shown & $\begin{array}{l}\text { Low dose of FK506 caused protective } \\
\text { effect against KA-induced cell death } \\
\text { in organothypic hippocampal slice } \\
\text { cultures. FK506 reduced ROS level } \\
\text { by SOD activation and apoptosis by } \\
\text { phospho-Akt activation. }\end{array}$ & Lee at al. 2010 \\
\hline $\begin{array}{l}\text { Ghrelin: an endoge- } \\
\text { nous ligand of growth } \\
\text { hormone secretagogue } \\
\text { receptor la }\end{array}$ & $\begin{array}{l}\text { Organotypic rat } \\
\text { spinal cord cultures } \\
\text { from 8-day-old } \\
\text { Sprague-Dawley rat } \\
\text { pups }\end{array}$ & Not shown & $\begin{array}{l}\text { Treating with ghrelin inhibited spinal } \\
\text { cord motoneuron death induced by } \\
\text { chronic glutamate excitotoxicity. This } \\
\text { substance activated ERK } 1 / 2 \text { and Akt } \\
\text { in motoneurons, and its protective ef- } \\
\text { fect was mediated by the MAPK and } \\
\text { PI3K/Akt pathways. It was also shown, } \\
\text { that ghrelin-induced Akt signaling is } \\
\text { associated with downstream inhibi- } \\
\text { tion of GSK-3 in motoneurons. }\end{array}$ & Lim et al., 2011 \\
\hline
\end{tabular}

Akt: protein kinase B; AMPA: $\alpha$-amino-3-hydroxy-5-methyl-4-isoxazole propionic acid; AMPAR: $\alpha$-amino-3-hydroxy-5-methyl-4isoxazole propionic acid receptor; CNS: central nervous systems; ERK1/2: extracellular-signal-regulated kinase 1/2; GSK-3 $\beta$ : Glycogen synthase kinase $3 \beta$; iGluR: ionotropic glutamate receptor; KA: kainic acid; KAR: kainic acid receptor; MAPK: mitogen activated protein kinase; mGluR: metabotropic glutamate receptors; NCCD: Nomenclature Committee on Cell Death; NMDA: N-methyl-D-aspartate; NMDAR: N-methyl-D-aspartate receptor; Nmnat: nicotinamide mononucleotide adenylyl transferase; PCD: programmed cell death; PI3K: Phosphatidylinositol 3-kinase; PNS: peripheral nervous systems; PSD: postsynaptic density proteins; Ufd2: ubiquitin fusion degradation protein 2; UPS: ubiquitin proteasome systemv; WD: Wallerian degeneration; WIds: Wallerian degeneration slow

each fragment of the chimeric Wlds protein has been examined in regard to WD induction, and it has been established that an overexpression of the nicotinamide mononucleotide adenylyl transferase (Nmnat) significanty delays this process, however the effect is less pronounced in comparison to the effect of the full Wlds protein. Many hypotheses have been proposed regarding the delay of WD by Nmnat, sug- gesting that this enzyme may have more than one function. Nmnat is a key regulatory enzyme in the biosynthesis of the nicotinamide adenine diculeotide (NAD+), which is essential for biosynthesis and regulation of ATP. Nmnat is also involved in regulation of gene expression by interactions with histone deacetylase (HDAC), and it regulates microtubules stability via interactions with sirtuin 
(SIRT-2) (Koike et al., 2008). So far, it has not been determined whether the protective effect of Nmnat overexpression results primarily from the improvement of cell metabolism, or is caused by other factors, such as Nmnat's interactions with other proteins (Koike et al., 2008). Analysis of the second part of the mutated $\mathrm{Wld}^{\mathrm{s}}$ protein - the N-terminal 70 amino acids fragment of Ufd 2 did not show its direct protective function in axons (Koike et al., 2008). However, it has been reported that this part of Ufd2 protein binds directly to $\mathrm{VCP} / \mathrm{p} 97$ (vasolincontaining protein), which plays a key role in the ubiquitin proteasome system (UPS) (Hilliard, 2009). In fact, other studies revealed that the Wallerian degeneration depends on the activity of UPS protein complex, since inhibition of UPS counteracts the process (Saxena and Caroni, 2007). In order to block WD, the inhibition of UPS activity must, however, occur 2-3 hours before axonal lesion, suggesting that this protein complex regulates only the early stages of axon degeneration (Luo and O'Leary, 2005). Other studies additionally point at the involvement of other proteins, such as: interleukin-6 (IL-6) (Lee et al., 2009), Rho GTPases (Yamagashi et al., 2005), TNF (tumor necrosis factor) (Uceyler and Sommer, 2006) in different stages of WD. Wallerian degeneration is not a typical cell death mechanism, since neurons undergoing this process remain alive, and therefore the WD is considered atypical (Kroemer et al., 2009).

\section{Concluding remarks}

Cell death is a process occurring very commonly in living organisms, during their developmental processes, normal physiology, as well as pathological conditions. The cells may undergo cell death via many pathways and mechanisms, among which four typical pathways are relatively best described, although more research is needed in this matter. The discovery of new, atypical forms of cell death has brought a lot of interesting information to this field of research. Nervous system plays an extremely important function in living organism, determining its contact with environment, but at the same time its regenerative abilities are very limited. It is therefore important to study and describe processes involved in death of the nervous system cells, and discover their causes. In the future it is possible that this type of studies will bring progress in the treatment of many dangerous diseases of the nervous system, including neoplasms and neurodegenerative diseases.

\section{Acknowledgements}

The paper was partially supported by scientific grants: N308565240 and N308289937 from the Ministry of Science and Higher Education (Poland). Authors would like to thank dr Anna WierzbickaWoś for excellent technical assistance in preparing the figure.

\section{References}

Alex A.B., Saunders G.W., Dalpe-Charron A., Reilly C.A., Wilcox K.S. CGX-1007 prevents excitotoxic cell death via actions at multiple types of NMDA receptors. Neurotoxicology, 32: 392-399, 2011.

Ashpole N.M. and Hudmon A. Excitotoxic neuroprotection and vulnerability with CaMKII inhibition. Mol. Cell. Neurosci., 46: 720-730, 2011.

Bergsbaken T., Fink S.L., Cookson B.T. Pyroptosis: host cell death and inflammation. Nature Rev. Microbiol., 7: 99-109, 2009.

Bevers M.B., Lawrence E., Maronski M., Starr N., Amesquita M., Neumar R.W. Knockdown of $\mathrm{m}$-calpain increases survival of primary hippocampal neurons following NMDA excitotoxicity. J. Neurochem, 108: 1237-1250, 2009.

Bliss R.M., Finckbone V.L., Trice J., Strahlendorf H., Strahlendorf J. Tumor necrosis factor- $\alpha$ (TNF- $\alpha)$ augments AMPA-induced Purkinje neuron toxicity. Brain Res., 1386: 1-14, 2011.

Bogaert E., Van Damme P., Poesen K., Dhondt J., Hersmus N., Kiraly D., Scheveneels W., Robberecht W., Van Den Bosch L. VEGF protects motor neurons against excitotoxicity by upregulation of GluR2. Neurobiol. Aging, 31: 2185-2191, 2010.

Caldero J., Brunet N., Tarabal O., Piedrafita L., Hereu M., Ayala V., Esquerda J.E. Lithium prevents excitotoxic cell death of motoneurons in organotypic slice cultures of spinal cord. Neurosci., 165: 1353-1369, 2010.

Cardoso A.I.C., Costa P., de Almeida L.P., Simoes S., Plesnila N., Culmsee C., Wagner E., Pedroso de Lima M.C. Tf-lipoplex-mediated c-Jun silencing improves neuronal survival following excitotoxic damage in vivo. J. Control. Release, 142: 392-403, 2010 . 
Casson R.J. and Franzo D. Possible role of excitotoxicity in the pathogenesis of glaucoma. Clin. Exp. Ophthalmol., 34: 54-63, 2006.

D'Antoni S., Berretta A., Seminara G., Longone P., Giuffrida-Stella A.M., Battaglia G., Sortino M.A., Nicoletti F., Catania M.V. A prolonged pharmacological blockade of type-5 metabotropic glutamate receptors protects cultured spinal cord motor neurons against excitotoxic death. Neurobiol. Dis., 42: 252-264, 2011.

Deng W., Yue Q., Rosenberg P.A., Volpe J.J., Jensen F.E. Oligodendrocyte excitotoxicity determined by local glutamate accumulation and mitochondrial function. J. Neurochem., 98: 213-222, 2006.

Di X., Yan J., Zhao Y., Zhang J., Shi Z., Chang Y., Zhao B. L-theanine protects the APP (Swedish mutation) transgenic SH-SY5Y cell against glutamate-induced excitotoxicity via inhibition of the NMDA receptor pathway. Neurosci., 168: 778786, 2010.

Domoki F., Kis B., Gaspar T., Snipes J.A., Bari F., Busija D.W. Rosuvastatin induces delayed preconditioning against L-glutamate excitotoxicity in cultured cortical neurons. Neurochem. Int., 56: 404-409, 2010.

Duncan K. The role of AMPA receptor-mediated excitotoxicity in ALS: is deficient RNA editing to blame? Curr. Anaesth. Crit. Care, 20: 227-235, 2009.

Flores-Soto M.E., Chaparro-Huerta V., EscotoDelgadillo M., Vazquez-Valls E., GonzálezCastañeda R.E., Beas-Zarate C. Structure and function of NMDA-type glutamate receptor subunits. Neurologia, 27: 301-310, 2012.

Forder J.P. and Tymianski M. Postsynaptic mechanisms of excitotoxicity: involvement of postsynaptic density proteins, radicals, and oxidant molecules. Neurosci., 158: 293-300, 2009.

Galluzzi L., Vitale I., Abrams J.M., Alnemri E.S., Baehrecke E.H., Blagosklonny M.V., Dawson T.M., Dawson V.L., El-Deiry W.S., Fulda S., Gottlieb E., Green D.R., Hengartner M.O., Kepp O., Knight R.A., Kumar S., Lipton S.A., Lu X., Madeo F., Malorni W., Mehlen P., Nunez G., Peter M.E., Piacentini M., Rubinsztein D.C., Shi Y., Simon H.U., Vandenabeele P., White E., Yuan J., Zhivotovsky B., Melino G., Kroemer G. Molecular definitions of cell death subroutines: recommendations of the Nomenclature Committee on Cell Death 2012. Cell Death Differ., 19: 107-120, 2012.

Gilmore A.P. Anoikis. Cell Death Differ., 12: 14731477, 2005.
Green D.R., Ferguson T., Zitvogel L., Kroemer G. Immunogenic and tolerogenic cell death. Nature Rev. Immunol., 9: 353-363, 2009.

Hilliard M.A. Axonal degeneration and regeneration: a mechanistic tug-of-war. J. Neurochem., 108: 23-32, 2009.

Hynd M.R., Scott H.L., Dodd P.R. Glutamatemediated excitotoxicity and neurodegeneration in Alzheimer's disease. Neurochem. Int., 45: 583595, 2004.

Ientile R., Macaione V., Teletta M., Pedale S., Torre V., Macaione S. Apoptosis and necrosis occurring in excitotoxic cell death in isolated chick embryo retina. J. Neurochem., 79: 71-78, 2001.

Jiang S.X., Zheng R.Y., Zeng J.Q., Li X.L., Han Z., Hou S.T. Reversible inhibition of intracellular calcium influx through NMDA receptors by imidazoline $\mathrm{I}_{2}$ receptor antagonists. Eur. J. Pharmacol., 629: 12-19, 2010.

Jorgensen J.R., Emerich D.F., Thanos C., Thompson L.H., Torp M., Bintz B., Fjord-Larsen L., Johansen T.E., Wahlberg L.U. Lentiviral delivery of Meteorin protects striatal neurons against excitotoxicity and reverses motor deficits in the quinolinic acid rat model. Neurobiol. Dis., 41: 160-168, 2011.

Koeppen A.H. Wallerian degeneration: history and clinical significance. J. Neur. Sci., 220: 115-117, 2004.

Koike T., Yang Y., Suzuki K., Zheng X. Axon \& dendrite degeneration: its mechanisms and protective experimental paradigms. Neurochem. Int., 52: 751-760, 2008.

Krantic S., Mechawar N., Reix S., Quirion R. Apoptosis-inducing factor: a matter of neuron life and death. Prog. Neurobiol., 81: 179-196, 2007.

Kroemer G., Galluzzi L., Vandenabeele P., Abrams J., Alnemri E.S., Baehrecke E.H., Blagosklonny M.V., El-Deiry W.S., Golstein P., Green D.R., Hengartner M., Knight R.A., Kumar S., Lipton S.A., Malorni W., Nunez G., Peter M.E., Tschopp J., Yuan J., Piacentini M., Zhivotovsky B., Melino G. Classification of cell death: recommendations of the Nomenclature Committee on Cell Death 2009. Cell Death Differ., 16: 3-11, 2009.

Lau A., Tymianski M. Excitotoxicity. In: Comprehensive toxicology. (Ed) McQuinn C. $2^{\text {nd }} e d n$. Elsevier Academic Press, 2010.

Lee A., Linghwood B.E., Bjorkman S.T., Miller S.M., Poronnik P., Barnett N.L., Colditz P., Pow D.V. Rapid loss of glutamine synthetase from astrocytes in response to hypoxia: implications for excitotoxicity. J. Chem. Neuroanat., 39: 211-220, 2010. 
Lee H.K., Seo I.A., Suh D.J., Hong J.I., Yoo Y.H., Park H.T. Interleukin-6 is required for the early induction of glial fibrillary acidic protein in Schwann cells during Wallerian degeneration. $J$. Neurochem., 108: 776-786, 2009.

Lim E., Lee S., Li E., Kim Y., Park S. Ghrelin protects spinal cord motoneurons against chronic glutamate-induced excitotoxicity via ERK1/2 and phosphatidylinositol-3-kinase/Akt/glycogen synthase kinase-3_pathways. Exp. Neurol., 230: 114122, 2011.

Lossi L., Cantile C., Tamagno I., Merighi A. Apoptosis in the mammalian CNS: lessons from animal models. Vet. J., 170: 52-66, 2005.

Luo L. and O'Leary D.D.M. Axon retraction and degeneration in development and disease. Аnпи. Rev. Neurosci., 28: 127-156, 2005.

Metha A., Prabhakar M., Kumar P., Deshmukh R., Sharma P.L. Excitotoxicity: bridge to various triggers in neurodegenerative disorders. Eur. J. Pharmacol., 698: 6-18, 2013.

Montoliu C., Humet M., Canales J.J., Burda J., Planells-Cases R., Sanchez-Baeza F., Carbonell T., Perez-Paya E., Messeguer A., Ferrer-Montiel A., Felipo V. Prevention of in vivo excitotoxicity by a family of trialkylglycines, a novel class of neuroprotectants. JPET, 301: 29-36, 2002.

Raff M.C., Whitmore A.V., Finn J.T. Axonal selfdestruction and neurodegeneration. Science, 296: 868-871, 2002.

Saxena S. and Caroni P. Mechanisms of axon degeneration: from development to disease. Prog. Neurobiol., 83: 174-191, 2007.
Sperandio S., de Belle I., Bredesen D.E. An alternative, nonapoptotic form of programmed cell death. PNAS, 97: 14376-14381, 2000.

Ting J.P.Y., Willingham S.B., Bergstralh D.T. NLRs at the intersection of cell death and immunity. Nature Rev. Immunol., 8: 372-379, 2008.

Uceyler N. and Sommer C. Wallerian degeneration and neuropathic pain. Drug Discov. Today: Dis. Mech., 3: 351-356, 2006.

Vincent P. and Mulle C. Kainate receptors in epilepsy and excitotoxicity. Neurosci., 158: 309-323, 2009.

Wang L., Hu B., Wong W.M., Lu P., Wu W., Xu X.M. Glial and axonal responses in areas of Wallerian degeneration of the corticospinal and dorsal ascending tracts after spinal cord dorsal funiculotomy. Neuropathol., 29: 230-241, 2009.

White E. Entosis: It's a Cell-Eat-Cell Word. Cell, 131: 840-842, 2007.

Wu Y. and Li S. Neuropeptide Y expression in mouse hippocampus and its role in neuronal excitotoxicity. Acta Pharmacol. Sin., 26: 63-68, 2005.

Yamagishi S., Fujitani M., Hata K., Kitajo K., Mitura F., Abe H., Yamashita T. Wallerian degeneration involves Rho/Rho-kinase signaling; J. Biol. Chem., 280: 20384-20388, 2005.

Yuan J., Lipinski M., Degterev A. Diversity in the Mechanisms of neuronal cell death. Neuron, 40: 401-413, 2003.

Yue Z., Friedman L., Komatsu M., Tanaka K. The cellular pathways of neuronal autophagy and their implication in neurodegenerative diseases. Biochim. Biophys. Acta, 1793: 1496-1507, 2009. 